\title{
Functional assessment of the NMDA receptor variant GluN2A
}

\section{${ }^{\mathrm{R} 586 \mathrm{~K}}$ [version 1; peer review: 1 approved, 2 approved with}

\section{reservations]}

\author{
Katie F.M. Marwick (D), Peter Parker, Paul Skehel, Giles Hardingham, \\ David J.A. Wyllie
}

Centre for Integrative Physiology, University of Edinburgh, Edinburgh, EH8 9XD, UK

V1 First published: 17 Mar 2017, 2:20

https://doi.org/10.12688/wellcomeopenres.10985.1

Latest published: $26 \mathrm{Apr} 2017,2: 20$

https://doi.org/10.12688/wellcomeopenres.10985.2

\section{Abstract}

Background: The N-methyl-D-aspartate receptor (NMDAR) is an ionotropic glutamate receptor that has important roles in synaptogenesis, synaptic transmission, and synaptic plasticity. Recently, a large number of rare genetic variants have been found in NMDAR subunits in people with neurodevelopmental disorders, and also in healthy individuals. One such is the GluN2AR586K variant, found in a person with intellectual disability. Identifying the functional consequences, if any, of such variants allows their potential contribution to pathogenesis to be assessed. Here, we assessed the effect of the GluN2A ${ }^{\text {R586K }}$ variant on NMDAR pore properties.

Methods: We expressed recombinant NMDARs with and without the


mouse neurons, and made electrophysiological recordings assessing $\mathrm{Mg}^{2+}$ block, single-channel conductance, mean open time and current density.

Results: The GluN2A ${ }^{\text {R586K }}$ variant was not found to influence any of the properties assessed.

Conclusions: Our findings suggest it is unlikely that the GluN2A R586K variant contributes to the pathogenesis of neurodevelopmental disorder.

\section{Keywords}

NMDAR, epilepsy, EEG, intellectual disability, electrophysiology, magnesium, conductance, neurons

\section{Open Peer Review}

Approval Status

1

2

3

\section{version 2}

(revision)

26 Apr 2017

version 1

17 Mar 2017

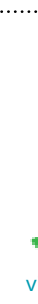

1. Paul L. Chazot, Durham University, Durham,

UK

2. Ian R. Mellor, University of Nottingham, Nottingham, UK

Helen Knight, University of Nottingham, Nottingham, UK

3. Laetitia Mony iD, INSERM (French National Institute of Health and Medical Research),

Paris, France

Any reports and responses or comments on the article can be found at the end of the article. 
Corresponding author: Katie F.M. Marwick (katie.marwick@ed.ac.uk)

Competing interests: No competing interests were disclosed.

Grant information: This work was funded by a Wellcome Trust Clinical PhD Fellowship to KM [102838] and by the Royal College of Psychiatrists in Scotland Small Projects Grant to KM.

The funders had no role in study design, data collection and analysis, decision to publish, or preparation of the manuscript.

Copyright: (c) 2017 Marwick KFM et al. This is an open access article distributed under the terms of the Creative Commons Attribution License, which permits unrestricted use, distribution, and reproduction in any medium, provided the original work is properly cited.

How to cite this article: Marwick KFM, Parker P, Skehel P et al. Functional assessment of the NMDA receptor variant GluN2A R586K [version 1; peer review: 1 approved, 2 approved with reservations] Wellcome Open Research 2017, 2:20

https://doi.org/10.12688/wellcomeopenres.10985.1

First published: 17 Mar 2017, 2:20 https://doi.org/10.12688/wellcomeopenres.10985.1 


\section{Introduction}

The N-methyl-D-aspartate receptor (NMDAR) is an ionotropic glutamate receptor that has important roles in synaptic transmission and synaptic plasticity, and has been implicated in a range of neurological disorders (reviewed in (Paoletti et al., 2013)). It is remarkable for its high $\mathrm{Ca}^{2+}$ permeability (MacDermott et al., 1986) and block by $\mathrm{Mg}^{2+}$, which underlies the NMDAR's voltage-dependence and hence role as a "molecular coincidence detector" (Mayer et al., 1984; Nowak et al., 1984). NMDARs are heterotetramers comprised of two GluN1 subunits and two others, of which GluN2A and GluN2B are the commonest in the mammalian forebrain (Monyer et al., 1994; Watanabe et al., 1992). GluN2A is predominantly expressed post-natally in rodents (Monyer et al., 1994; Watanabe et al., 1992) and humans (Law et al., 2003), where it is thought to frequently associate with GluN2B subunits to form triheteromeric GluN2A/2B NMDARs (reviewed in Wyllie et al., 2013).

Recently, advances in sequencing technology have allowed a large number of GluN2A mutations to be identified in individuals with a range of neurodevelopmental disorders, including epilepsy, intellectual disability, autism and schizophrenia (Burnashev \& Szepetowski, 2015). Many of these mutations are missense, potentially resulting in a NMDAR with altered function. Identifying the functional consequences, if any, of such mutations may allow insight into key mechanistic pathways underlying the neurodevelopmental disorders with which they are associated. However, it is likely that some mutations are not relevant to the disorders of their carriers, leading either to receptors with no altered function or alterations that are easily compensated for. Distinguishing between mutations that may be pathogenic, and those that are coincidental, aids mechanistic understanding, therapeutics, and genetic counselling.

GluN2 $\mathrm{A}^{\mathrm{R} 586 \mathrm{~K}}$ was first identified as being maternally inherited in a person with intellectual disability and either epilepsy or an abnormal EEG (Endele et al., 2010). The phenotype of the proband's mother was not reported. GluN2 $\mathrm{A}^{\mathrm{R} 586 \mathrm{~K}}$ has undergone no previous functional assessment. It alters a residue in the cytosolic loop linking the subunit's M1 and M2 pore domains (Monyer et al., 1992), which has so far not been linked to any particular function. However, the loop's proximity to the pore suggests that any functional consequences could include an impact on ion permeation and/or block of the pore by $\mathrm{Mg}^{2+}$ ions.

In the present study, we performed the first known functional analysis of the GluN2A ${ }^{\mathrm{R} 586 \mathrm{~K}}$ variant. We made electrophysiological recordings from NMDARs containing mutant subunits expressed in Xenopus laevis oocytes and primary cultured neurons, allowing us to assess the variant's impact on block by $\mathrm{Mg}^{2+}$ ions, single channel conductance, mean open time and NMDAR current density. We found that the GluN2 $\mathrm{A}^{\mathrm{R} 586 \mathrm{~K}}$ variant did not affect any of the parameters assessed.

\section{Materials and Methods}

\section{Constructs}

The cDNA for wild type human NMDA subunit GluN1-1a (hereafter GluN1) (GenBank accession code NP_015566), GluN2A
(GenBank accession code NP_000824; (Hedegaard et al., 2012)) and GluN2A ${ }^{\text {R586K }}$ were gifts from Dr Kasper Hansen and Dr Honjie Yuan (University of Emory, Atlanta, GA, USA). The GluN2A ${ }^{\mathrm{R} 586 \mathrm{~K}}$ variant was confirmed by Sanger sequencing. All cDNAs were expressed via a pCI-neo vector.

\section{Two-electrode voltage-clamp recordings}

cRNA for wild type and mutant subunits was synthesized from linearized plasmid DNA as runoff transcripts using the T7 polymerase mMessage machine RNA synthesis kit (Life Technologies Ltd, Paisley, UK). Each oocyte was injected with 3.7-9 ng of cRNA, comprising a 1:1 molar ratio of GluN1 and GluN2A diluted in RNAse free water.

Stage V-VI X. laevis oocytes were obtained from the UK Xenopus centre (Portsmouth, UK) and from Diaclean (CastropRauxel, Germany), collagenased (200 units/ml for 60 minutes), then manually defolliculated prior to injection. After injection, oocytes were placed in separate wells of 24-well plates containing a modified Barth's solution with composition (in $\mathrm{mM}$ ): $88 \mathrm{NaCl}, 1 \mathrm{KCl}, 2.4$ $\mathrm{NaHCO}_{3}, 0.82 \mathrm{MgCl}_{2}, 0.44 \mathrm{CaCl}_{2}, 0.33 \mathrm{Ca}\left(\mathrm{NO}_{3}\right)_{2}, 15$ Tris- $\mathrm{HCl}$; adjusted to $\mathrm{pH} 7.35$ with $\mathrm{NaOH}$. This solution was supplemented with $50 \mathrm{IU} / \mathrm{ml}$ penicillin, $50 \mathrm{mg} / \mathrm{ml}$ streptomycin and $50 \mathrm{mg} / \mathrm{ml}$ tetracycline. Oocytes were placed in an incubator $\left(16-21^{\circ} \mathrm{C}\right)$ for 24-48 hours to encourage receptor expression and subsequently stored at $4^{\circ} \mathrm{C}$. Recordings were made $48-96$ hours post injection.

Two-electrode voltage-clamp recordings were made at room temperature $\left(18-21^{\circ} \mathrm{C}\right)$ from oocytes that were placed in a solution that contained (in $\mathrm{mM}$ ): $115 \mathrm{NaCl}, 2.5 \mathrm{KCl}, 10 \mathrm{HEPES}, 1.8 \mathrm{BaCl}_{2}$, 0.01 EDTA; pH 7.35 with $\mathrm{NaOH}$. Recordings were made using a GeneClamp 500B amplifier (Molecular Devices, Union City, CA, USA). Current and voltage electrodes were made from thin-walled borosilicate glass (GC150TF-7.5, Harvard Apparatus, Kent, UK) using a PP-830 electrode puller (Narashige Instruments, Tokyo, Japan). Filling with $3 \mathrm{M} \mathrm{KCl}$ gave resistances of between 0.2 and $1.5 \mathrm{M} \Omega$. Application of solutions was determined manually. Data were filtered at $10 \mathrm{~Hz}$ and digitized at $100 \mathrm{~Hz}$ via a 1401 plus analogue-digital interface (Cambridge Electronic Design, Cambridge, UK) using WinEDR software (version 3.2.7; Strathclyde Electrophysiology Software, Strathclyde University, Glasgow, UK). Oocytes were voltage-clamped at $-40,-60$ or $-80 \mathrm{mV}$. Recordings were rejected if the holding current (in $\mathrm{nA}$ ) was greater than three times the holding potential (in $\mathrm{mV}$ ), or if the holding current drifted by more than $10 \%$ of the agonist response across the course of the experiment.

\section{Single-channel voltage-clamp recordings}

Single-channel voltage-clamp recordings were made at room temperature from outside-out patches pulled from oocytes that were placed in a solution that contained (in $\mathrm{mM}$ ): $125 \mathrm{NaCl}$, $3 \mathrm{KCl}, 1.25 \mathrm{NaH}_{2} \mathrm{PO}_{4}, 20$ HEPES, $0.85 \mathrm{CaCl}_{2}, 0.01$ EDTA; $\mathrm{pH} 7.35$ with $\mathrm{NaOH}$. Steady state recordings were made in the presence of $30 \mu \mathrm{M}$ glutamate and $30 \mu \mathrm{M}$ glycine. Recording durations varied from 30 seconds to 5 minutes. Prior to recording, vitelline membranes were manually removed from oocytes following placement in a hypertonic solution that contained (in $\mathrm{mM}$ ): 200 sodium methyl sulphate, $20 \mathrm{KCl}, 10 \mathrm{HEPES}, 1 \mathrm{MgCl}_{2}$; $\mathrm{pH} 7.4$ 
with $\mathrm{NaOH}$. Recordings were made using an AxoPatch 1D amplifier (Molecular Devices). Electrodes were made using thick walled borosilicate glass (GC150F-7.5; Harvard Apparatus) using a P-87 electrode puller (Sutter Instrument, Novato, CA, USA) and their tips fire polished to give resistances of 7 to $12 \mathrm{M} \Omega$ when filled with internal solution containing (in $\mathrm{mM}$ ): $2.5 \mathrm{NaCl}, 141 \mathrm{~K}$-gluconate, 10 HEPES, 11 EGTA; pH 7.4 with KOH. Electrode tips were coated in silicone elastomer ("sylgard 184"; Dow Corning, Wiesbaden, Germany) to reduce capacitance. Application of solutions was controlled manually. Data were prefiltered at $2 \mathrm{kHz}(-3 \mathrm{~dB} ; 8$ th order Bessel filter) and digitized at $20 \mathrm{kHz}$ via a Micro 1401 analogue-digital interface (Cambridge Electronic Design) using WinEDR software (v 3.2.7). Patches were voltage-clamped at -60 or $-100 \mathrm{mV}$.

WinEDR v3.3.7 was used to idealise the traces (using a transition threshold of $50 \%$ of the unitary conductance level and a $100 \mu \mathrm{s}$ open and shut resolution), to fit Gaussian curves to amplitude histograms and to fit exponential curves to dwell time durations (all curves fitted using iterative maximum likelihoods). Any openings where more than one channel was open simultaneously were discarded. Conductance was calculated by dividing the current amplitude by the holding potential.

\section{Preparation and transfection of neurons}

Animal breeding, maintenance and procedures were performed in accordance with the UK Animal Scientific Procedures Act (1986). Culturing was a modified version of (Furshpan \& Potter, 1989). Brains from E17.5 CD1 mice (sex not determined, on average 15 mice per culture) were microdissected in medium containing (in mM): $8.8 \mathrm{Na}_{2} \mathrm{SO}_{4}, 27 \mathrm{~K}_{2} \mathrm{SO}_{4}, 5.3 \mathrm{MgCl}_{2}, 0.23 \mathrm{CaCl}_{2}, 0.9$ HEPES, $0.001 \%$ Phenol Red, 18 D-glucose, 0.0005 kynurenic acid; adjusted to $\mathrm{pH} 7.35$ with $\mathrm{NaOH}$. Cortices were incubated at $37^{\circ} \mathrm{C}$ for 40 minutes in papain enzyme (36,000 USP units/ml; Worthington Biochemical Corporation, Lakewood, NJ, USA) then washed and triturated in NeuroBasal A medium (supplemented with $1 \%$ rat serum (Harlan Laboratories, Bicester, UK), $1 \times \mathrm{B}-27$ supplement, $1 \%$ antibacterial/antimycotic and $1 \mathrm{mM}$ glutamine). The cell suspension was diluted in opti-MEM (supplemented with $20 \mathrm{mM}$ glucose and $1 \%$ antibacterial/antimycotic) to give an end concentration of 1 hemisphere per $7 \mathrm{ml}$, and $0.5 \mathrm{ml} /$ coverslip plated onto $13 \mathrm{~mm}$ diameter coverslips precoated with poly-D-lysine $\left(1.33 \% \mathrm{w} / \mathrm{v}\right.$ in $\left.\mathrm{H}_{2} 0\right)$ and laminin $(0.5 \%$ w/v) (Roche, Basel, Switzerland) in 24-well plates. Plates were kept at $37^{\circ} \mathrm{C}$ in a humidified $5 \% \mathrm{CO}_{2}$ incubator for 2.5 hours before replacement of the cell suspension with supplemented NeuroBasal A. On day in vitro (DIV) $4,1 \mathrm{ml} /$ well of supplemented NeuroBasal A containing $9.6 \mathrm{mM}$ cytosine $\beta$-D-arabinofuranoside hydrochloride was added to the cells.

Neurons were transfected on DIV 7 or 8 with plasmids containing cDNA for wild type and mutant GluN2A subunits, or the inert control $\beta$ globin, using Lipofectamine 2000 (hereafter referred to as lipofectamine) in serum free non-trophic transfection medium composed of: $10 \%$ minimum essential media (MEM; +Earles, -L-glutamine), $88 \%$ Salt-Glucose-Glycine (comprising in $\mathrm{mM}$
$114 \mathrm{NaCl}, 26 \mathrm{NaHCO}_{3}, 5.3 \mathrm{KCl}, 1 \mathrm{MgCl}_{2}, 2 \mathrm{CaCl}_{2}, 10$ HEPES, 1 glycine, 30 D-glucose, 0.5 sodium pyruvate, with phenol red 0.001\%; (Bading et al., 1993)) supplemented with $1 \%$ antibiotic/ antimycotic and $1 \%$ insulin-transferrin-selenium supplement. For each cover slip, $2.3 \mu \mathrm{l}$ of lipofectamine was mixed with $575 \mathrm{ng}$ plasmid DNA comprising a 2:1 mass ratio of GluN2A/GluN2B and eGFP cDNA. Cotransfection rate was $100 \%$ [cells were cotransfected using the above technique with cDNA encoding two fluorescent proteins (eGFP and mCherry) and observed for overlapping fluorescence 48 hours post transfection: 47/47 cells observed over 3 cover slips showed co-transfection]. Electrophysiological recordings were made 48 hours post transfection.

\section{Whole-cell recordings in cultured neurons}

Recordings from cultured neurons were made at room temperature with neurons superfused (at a flow rate of $2 \mathrm{~mL} / \mathrm{min}$ ) with external recording solution composed of (in $\mathrm{mM}$ ) $150 \mathrm{NaCl}, 2.8 \mathrm{KCl}, 10$ HEPES, $2 \mathrm{CaCl}_{2}, 10$ glucose, 0.1 glycine, 0.003 tetrodotoxin; pH 7.35 using $\mathrm{NaOH}$ (300-330 mOsm). Transfected cells were identified by eGFP expression (excitation at $470 \mathrm{~nm}$, coolLED pE-100 (coolLED Ltd, Andover, UK)). In total, $150 \mu \mathrm{M}$ NMDA was applied briefly twice to elicit desensitization, then reapplied until a steady state response was achieved (around 10 seconds of application) at which point $1 \mathrm{mM} \mathrm{MgCl}$ was co-applied until a new steady state was achieved. Experiments were then repeated after perfusion with $3 \mu \mathrm{M}$ ifenprodil for one minute. Application of solutions was controlled manually. Patch-pipettes were made from thick-walled borosilicate glass (GC150F-7.5; Harvard Apparatus) using a P-87 puller (Sutter Instruments) to give a resistance of 2-4 M $\Omega$ when filled with internal solution containing (in $\mathrm{mM}$ ): $141 \mathrm{~K}$-gluconate, $2.5 \mathrm{NaCl}, 10$ HEPES, 11 EGTA; $\mathrm{pH}$ 7.3 with $\mathrm{KOH}(300 \mathrm{mOsm})$. Currents were recorded using an Axopatch 200B amplifier (Molecular Devices). Data were filtered at $2 \mathrm{kHz}$ and digitized at $20 \mathrm{kHz}$ via a National Instruments BNC2090A analogue-digital interface (National Instruments) using WinEDR software (v 3.2.7). Neurons were voltage-clamped at -65 $\mathrm{mV}$, and recordings were rejected if the holding current was greater than $150 \mathrm{pA}$ or if the series resistance was greater than $30 \mathrm{M} \Omega$, or increased by greater than $20 \%$ during the course of the recording. Capacitance was calculated by calculating the area under the current response to a $5 \mathrm{mV}$ test pulse plotted against time (giving the charge) and dividing by the voltage of the test pulse. Capacitance provides an estimate of cell surface area. Current density was then calculated as current / capacitance.

\section{Data analysis}

Bar graphs depict individual cells (circles), means (columns) and standard error of the mean (SEM; error bars). R (v 3.1.2; R Core Team, 2014) was used to perform statistical tests. Comparisons between multiple means were performed by ANOVA. Comparisons between two means were performed by independent, two-tailed, Welch t-tests (which do not assume equal variance between groups), unless otherwise stated. The significance level used was $\mathrm{p}<0.05$, corrected for multiple comparisons using the Bonferroni method. In figures, * indicates corrected significance levels of $\mathrm{p}<0.05$, ** indicates $\mathrm{p}<0.01$ and $* * *$ indicates $\mathrm{p}<0.001$. 


\section{Materials}

NMDA, NMDAR antagonists, ifenprodil and tetrodotoxin were purchased from Tocris Bioscience (Bristol, UK). Media, media supplements, Lipofectamine 2000, antibiotic/antimycotic and B-27 were purchased from Invitrogen (Carlsbad, CA, USA). The remaining substances were purchased from Sigma-Aldrich (St. Louis, MO, USA) unless stated otherwise in the text.

\section{Results}

The GluN2A ${ }^{\text {R586K }}$ mutation has no effect on $\mathrm{Mg}^{2+}$ block or current density

We first expressed GluN2 $\mathrm{A}^{\mathrm{WT}}$ and GluN2 $\mathrm{A}^{\mathrm{R} 586 \mathrm{~K}}$-containing NMDARs in $X$. laevis oocytes and made two-electrode voltage clamp recordings of block by $\mathrm{Mg}^{2+}$ of glutamate-evoked currents. We found no effect of GluN2A $\mathrm{A}^{\mathrm{R} 586 \mathrm{~K}}$ on block by $\mathrm{Mg}^{2+}$ (Figure $1 \mathrm{~A}-\mathrm{C}$ ).

To assess for any neuron-specific consequences of the variant, we then used transient transfection to over-express GluN2 $\mathrm{A}^{\mathrm{R} 586 \mathrm{~K}}$ in cultured primary mouse cortical neurons. The interpretation of results in neurons is complicated by each cell giving a NMDAevoked response that arises in part from endogenous NMDAR subunits and in part from transfected subunits. The age of culture used (DIV 9) was chosen so that virtually all the endogenous GluN2 subunits were GluN2B (McKay et al., 2012). The GluN2B selective negative allosteric modulator ifenprodil could therefore be used to suppress the contribution of endogenous NMDARs and to confirm the transfection of the subunit of interest (GluN2B diheteromers show $80 \%$ block, but GluN2A diheteromers minimal block at the concentration of ifenprodil used $(3 \mu \mathrm{M})$ (Williams, 1993)).

GluN2A $\mathrm{A}^{\mathrm{R} 586 \mathrm{~K}}$ expression was confirmed by reduced ifenprodil sensitivity compared to control transfections (Figure 2A-C; Table 1). As with oocytes, no effect was found on $\mathrm{Mg}^{2+}$ block in neurons (Figure 2A,B,D; Table 1). Current density was also unaffected by the GluN2A ${ }^{\mathrm{R} 586 \mathrm{~K}}$ mutation (Figure 2A,B,E; Table 1).

\section{The GluN2A ${ }^{\text {R586K }}$ mutation has no effect on single-channel} properties

Finally, we used outside-out patches pulled from oocytes to assess the impact of GluN2 $\mathrm{A}^{\mathrm{R} 586 \mathrm{~K}}$ on NMDAR single-channel conductance and mean open time. We found GluN2A $\mathrm{A}^{\mathrm{R} 586 \mathrm{~K}}$ to have no effect (Figure 3A-D).
A



B



C

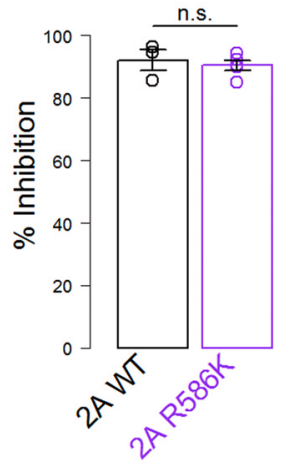

Figure 1. NMDARs containing GluN2A ${ }^{\mathrm{R} 586 \mathrm{~K}}$ show normal block by $\mathbf{M g}^{2+}$ when expressed in oocytes. (A and $\left.\mathbf{B}\right)$ Representative twoelectrode voltage-clamp recordings from oocytes expressing GluN2AWT or GluN2A ${ }^{\text {R586K }}$-containing NMDARs, showing current evoked by glutamate $(30 \mu \mathrm{M})$ and inhibition by an approximately physiological concentration of $\mathrm{Mg}^{2+}(1 \mathrm{mM})$, in the continuous presence of glycine $(30 \mu \mathrm{M})$. Holding potential $-60 \mathrm{mV}$. Responses are normalised to the peak amplitude. (C) Summary data showing percentage block by $\mathrm{Mg}^{2+}$ at $-60 \mathrm{mV}$. A t-test showed no significant difference between $\mathrm{Mg}^{2+}$ block in oocytes expressing GluN2AWT $(n=3,92 \pm 3 \%)$ and GluN2A ${ }^{\text {R586K }}$ $(\mathrm{n}=5,90 \pm 2 \%, \mathrm{t}(2.9)=0.46, \mathrm{p}=0.68)$. 
A



D

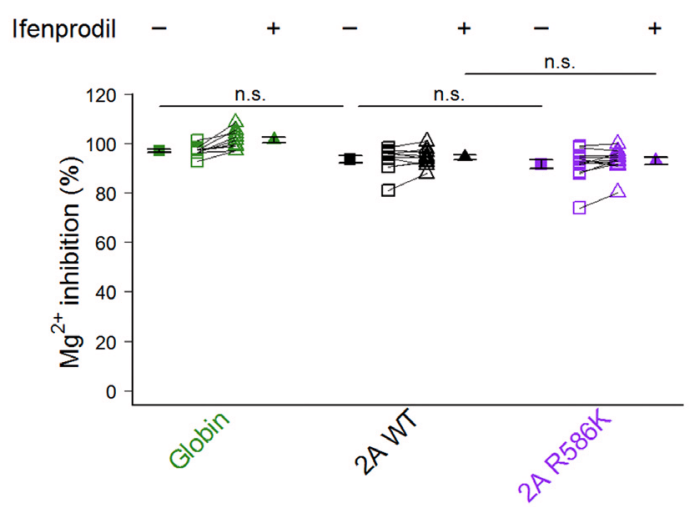

B

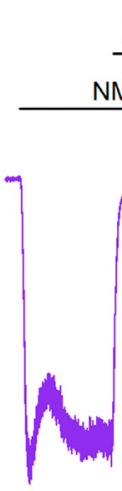

$2 \mathrm{~A}^{\mathrm{R} 586 \mathrm{~K}}$

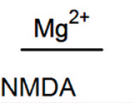

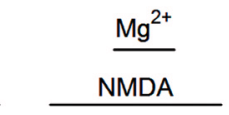

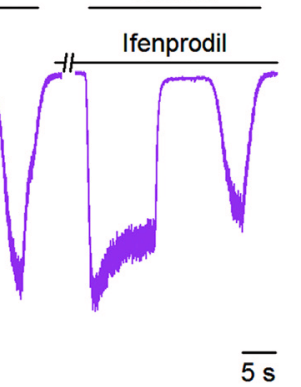

C

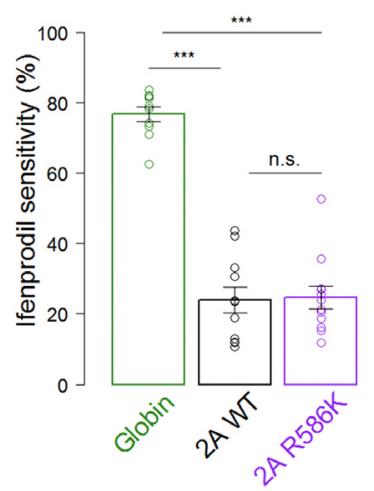

$\mathrm{E}$



Figure 2. NMDARs containing GluN2A ${ }^{\mathrm{R} 586 \mathrm{~K}}$ show normal block by $\mathrm{Mg}^{2+}$ and normal current density when expressed in neurons. (A and B) Representative whole-cell voltage-clamp recordings from day in vitro (DIV) 9 neurons transfected with an inert control, GluN2AwT or GluN2A ${ }^{\text {R586K }}$, showing inhibition of current evoked by saturating NMDA (150 $\left.\mu \mathrm{M}\right)$ by $\mathrm{Mg}^{2+}(1 \mathrm{mM})$ before and after one minute of ifenprodil $(3 \mu \mathrm{M})$ application. Holding potential $-65 \mathrm{mV}$. Responses are normalised to the peak amplitude. (C) Summary data showing percentage inhibition by ifenprodil, recorded from neurons as shown in $\mathbf{A}$ and $\mathbf{B}$. A one-way ANOVA showed a significant effect of transfected subunit $(F(2,30)=91, p=1.8 \mathrm{e}-13)$, with post hoc t-tests $\left(p_{\text {corr }}=0.15\right)$ showing that neurons transfected with GluN2AwT showed lower ifenprodil sensitivity than control transfection cells $(t(15.7)=12.6, p=1.3 e-9)$, as did neurons transfected with GluN2A ${ }^{\mathrm{R} 586 \mathrm{~K}}(\mathrm{t}(18.3)=13.8, \mathrm{p}=3.9 \mathrm{e}-11)$, and with no difference between GluN2A ${ }^{\mathrm{WT}}$ and GluN2A ${ }^{\mathrm{R} 586 \mathrm{~K}}(\mathrm{t}(20.3)=0.2, p=0.88)$. These results confirm that the GluN2A ${ }^{\text {R586K }}$ subunits were successfully trafficked to the membrane in neurons. (D) Summary data showing percentage inhibition by Mg ${ }^{2+}$ in the presence and absence of ifenprodil, recorded from neurons as shown in $\mathbf{A}$ and $\mathbf{B}$. A two-way ANOVA showed a significant effect of transfected subunit $(F(2,30)=7.5, p=0.0022)$ on $\mathrm{Mg}^{2+}$ block and of the presence/absence of ifenprodil $(F(1,30)=17.1, p=0.0003)$, with a significant interaction $(F(2,30)=4.4, p=0.021)$. However, post hoc t-tests $\left(p_{c o r r}=0.15\right)$ showed no difference in $\mathrm{Mg}^{2+}$ block in the absence of ifenprodil in neurons transfected with GluN2A ${ }^{\text {R586K }}$ compared to GluN2A $A^{\text {WT }}(t(20.3)=0.86, p=0.40)$, and no difference between GluN2A ${ }^{\text {WT }}$ and neurons transfected with an inert control $(\mathrm{t}(13.8)=2.2, \mathrm{p}=0.049)$. There was also no reduction in $\mathrm{Mg}^{2+}$ block associated with GluN2A ${ }^{\mathrm{R} 586 \mathrm{~K}}$ vs GluN2A ${ }^{\mathrm{WT}}$ in the presence of ifenprodil, when a greater proportion of response was attributable to the transfected subunits of interest $(t(20.2)=0.87, p=0.40)$. (E) Summary data showing current density evoked by NMDA in the presence and absence of ifenprodil, recorded from neurons as shown in $\mathbf{A}$ and $\mathbf{B}$. A two-way ANOVA showed a significant effect of transfected subunit $(F(2,30)=7.5, p=0.0023)$ and of the presence/absence of ifenprodil $(F(1,30)=139, p=9 e-13)$, with a significant interaction $(F(2,30)=16.8, p=1.3 e-5)$. However, post hoc t-tests $\left(p_{\text {corr }}=0.15\right)$ showed no difference in current density in the absence of ifenprodil in neurons transfected with GluN2A ${ }^{\text {R586K }}$ compared to GluN2A ${ }^{\text {WT }}(t(20.9)=$ $0.5, p=0.61)$, and no difference between GluN2AWT and neurons transfected with an inert control $(t(18.8)=1.2, p=0.24)$. There was also no reduction in current density associated with GluN2A ${ }^{\text {R586K }}$ vs GluN2AWT in the presence of ifenprodil $(t(21)=0.44, p=0.66)$. Data are means \pm SEM. Circles represent individual cells. See Table 1 for means and sample sizes. 
Table 1. $\mathbf{M g}^{2+}$ block, current density and ifenprodil sensitivity in neurons transfected with an inert control (Globin), GluN2A ${ }^{\mathrm{WT}}$ and GluN2A ${ }^{\mathrm{R} 586 \mathrm{~K}}$ subunits.

\begin{tabular}{|l|c|c|c|c|c|c|}
\hline & $\begin{array}{l}\text { Ifenprodil } \\
\text { sensitivity }\end{array}$ & $\begin{array}{c}\mathbf{M g}^{2+} \text { block } \\
\text { (\%) }\end{array}$ & $\begin{array}{c}\mathbf{M g}^{2+} \text { block (\%) } \\
\text { + Ifenprodil }\end{array}$ & $\begin{array}{c}\text { Current density } \\
\text { (pA/pF) }\end{array}$ & $\begin{array}{c}\text { Current density } \\
\text { (pA/pF) + Ifenprodil }\end{array}$ & $\mathbf{n}$ \\
\hline Globin & $77 \pm 2$ & $97 \pm 1$ & $101 \pm 1$ & $48 \pm 6$ & $11 \pm 1$ & 10 \\
\hline GluN2A ${ }^{W T}$ & $24 \pm 4$ & $94 \pm 1$ & $94 \pm 1$ & $57 \pm 5$ & $44 \pm 5$ & 11 \\
\hline GluN2A $^{\text {R586K }}$ & $25 \pm 3$ & $92 \pm 2$ & $93 \pm 1$ & $62 \pm 6$ & $47 \pm 5$ & 12 \\
\hline
\end{tabular}

$\mathrm{n}$ refers to number of neurons. Data are means \pm SEM. Statistical comparisons are reported in the Figure 2 legend. $\mathrm{Mg}^{2+}$ concentration used was $1 \mathrm{mM}$; ifenprodil $3 \mu \mathrm{M}$.

A

$2 A^{W T}$

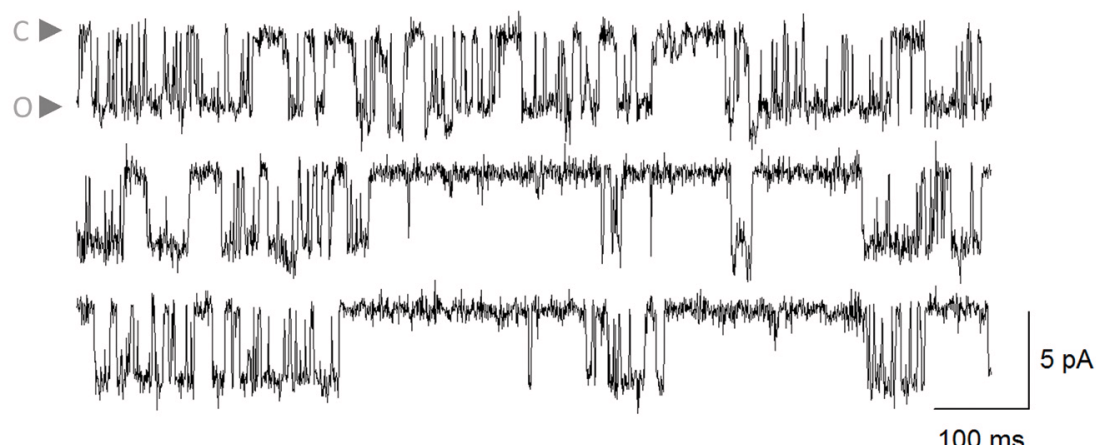

B

$2 A^{R 586 K}$

$100 \mathrm{~ms}$

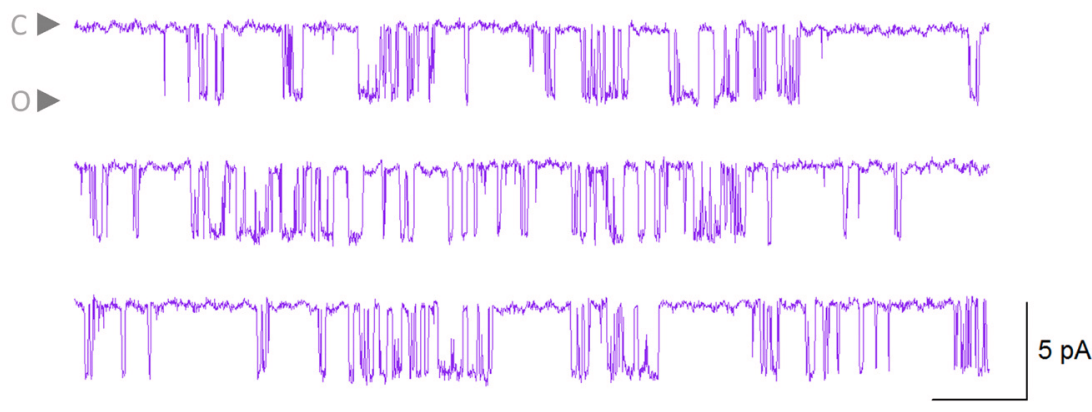

$100 \mathrm{~ms}$

C

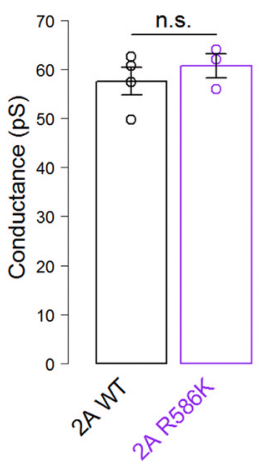

D

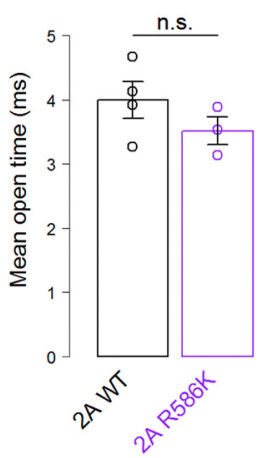

Figure 3. NMDARs containing GluN2A ${ }^{\text {R586K }}$ show normal single-channel conductance. (A and B) Representative voltage-clamp recordings made from outside-out patches from oocytes transfected with GluN2A $A^{\text {WT }}$ or GluN2A ${ }^{\text {R586K }}$-containing NMDARs in the presence of glutamate $(30 \mu \mathrm{M})$ and glycine $(30 \mu \mathrm{M})$. "C" = closed, "O" = open. (C) Summary data showing conductance, calculated as current amplitude/ holding potential. A t-test showed no significant difference in conductance in oocytes expressing GluN2AWT $(n=4,58 \pm 3$ pS, total events $=$ 2555) and GluN2A ${ }^{\text {R586K }}(n=3,61 \pm 2 p S$, total events $=1139, t(5.0)=0.84, p=0.44)$. (D) Summary data showing tau for mean open time, calculated by fitting exponential curves to open time frequency distributions. A single exponential was fitted in each case. A t-test showed no significant difference in mean open time in oocytes expressing GluN2AwT ( $n=4,4.0 \pm 0.3 \mathrm{~ms})$ and GluN2A ${ }^{\mathrm{R} 586 \mathrm{~K}}(\mathrm{n}=3,3.5 \pm 0.2 \mathrm{~ms}$, $\mathrm{t}(5.0)=1.32, \mathrm{p}=0.24)$. Data are means $\pm \mathrm{SEM}$. Circles represent individual cells. 


\section{Discussion}

In the present study, we investigated the functional consequences of a GluN2A point variation found previously in a person with epilepsy/EEG abnormalities and intellectual disability. Using heterologous systems, we showed that the GluN2 $\mathrm{A}^{\mathrm{R} 586 \mathrm{~K}}$ variant had no effect on any of the properties assessed: $\mathrm{Mg}^{2+}$ block, current density, conductance or mean open time.

The lack of functional consequences for the GluN2 $\mathrm{A}^{\mathrm{R} 586 \mathrm{~K}}$ variant is in contrast to existing findings for several disease-associated NMDAR mutations, which have been found to have a substantial impact on NMDAR properties, including $\mathrm{Mg}^{2+}$ block (Burnashev \& Szepetowski, 2015).

It was difficult to hypothesise what the likely impact of the GluN2 $\mathrm{A}^{\mathrm{R} 586 \mathrm{~K}}$ variant might be, as little is known about the function of the M1-M2 linker region in which it is found. It is possible that the variant affects other properties that have not been investigated in this study. It is also possible that the variant does not alter NMDAR function, and that its presence in an individual with neurodevelopmental disorder was coincidental. This is particularly likely as the variant was inherited, and because it has also subsequently been found in two out of 60,706 individuals without severe paediatric disease collated by the Exome Aggregation Consortium (Lek et al., 2016).

In conclusion, our functional studies suggest that the GluN2A $\mathrm{A}^{\mathrm{R} 586 \mathrm{~K}}$ variant is probably benign.

\section{Data availability}

Data are deposited in project GluN2A R586K, Open Science Framework: DOI, 10.17605/OSF.IO/AWCNQ (Marwick, 2017).

\section{Author contributions}

KM, GH, DW and PS conceived the study. KM and DW designed the experiments. KM and PP carried out the research. KM prepared the first draft of the manuscript. All authors were involved in the revision of the draft manuscript and have agreed to the final content.

\section{Competing interests}

No competing interests were disclosed.

\section{Grant information}

This work was funded by a Wellcome Trust Clinical PhD Fellowship to KM [102838] and by the Royal College of Psychiatrists in Scotland Small Projects Grant to KM.

The funders had no role in study design, data collection and analysis, decision to publish, or preparation of the manuscript.

\section{Acknowledgements}

We thank Sean McKay and Matthew Livesey for assistance with teaching techniques.
Bading $\mathrm{H}$, Ginty DD, Greenberg ME: Regulation of gene expression in hippocampal neurons by distinct calcium signaling pathways. Science. 1993; 260(5105): 181-186.

PubMed Abstract | Publisher Full Text

Burnashev N, Szepetowski P: NMDA receptor subunit mutations in neurodevelopmental disorders. Curr Opin Pharmacol. 2015; 20: 73-82. PubMed Abstract | Publisher Full Text

Endele S, Rosenberger G, Geider K, et al:: Mutations in GRIN2A and GRIN2B encoding regulatory subunits of NMDA receptors cause variable neurodevelopmental phenotypes. Nat Genet. 2010; 42(11): 1021-6. PubMed Abstract | Publisher Full Text

Furshpan EJ, Potter DD: Seizure-like activity and cellular damage in rat hippocampal neurons in cell culture. Neuron. 1989; 3(2): 199-207. PubMed Abstract | Publisher Full Text

Hedegaard MK, Hansen KB, Andersen KT, et al.: Molecular pharmacology of human NMDA receptors. Neurochem Int. 2012; 61(4): 601-609. PubMed Abstract | Publisher Full Text | Free Full Text

Law AJ, Weickert CS, Webster MJ, et al.: Expression of NMDA receptor NR1, NR2A and NR2B subunit mRNAs during development of the human hippocampal formation. Eur J Neurosci. 2003; 18(5): 1197-1205.

PubMed Abstract | Publisher Full Text

Lek M, Karczewski KJ, Minikel EV, et al.: Analysis of protein-coding genetic variation in 60,706 humans. Nature. 2016; 536(7616): 285-291. PubMed Abstract | Publisher Full Text | Free Full Text

MacDermott AB, Mayer ML, Westbrook GL, et al.: NMDA-receptor activation increases cytoplasmic calcium concentration in cultured spinal cord neurones. Nature. 1986; 321(6069): 519-22.

PubMed Abstract | Publisher Full Text

Marwick K: "GluN2A R586K”. Open Science Framework. March 8. 2017. Data Source

Mayer ML, Westbrook GL, Guthrie PB: Voltage-dependent block by $\mathbf{M g}^{2+}$ of
NMDA responses in spinal cord neurones. Nature. 1984; 309(5965): 261-263. PubMed Abstract | Publisher Full Text

McKay S, Griffiths NH, Butters PA, et al:: Direct pharmacological monitoring of the developmental switch in NMDA receptor subunit composition using TCN 213, a GluN2A-selective, glycine-dependent antagonist. Br J Pharmacol. 2012; 166(3): 924-37.

PubMed Abstract | Publisher Full Text | Free Full Text

Monyer $\mathrm{H}$, Burnashev N, Laurie DJ, et al.: Developmental and regional expression in the rat brain and functional properties of four NMDA receptors. Neuron. 1994; 12(3): 529-40.

PubMed Abstract | Publisher Full Text

Monyer $\mathrm{H}$, Sprengel R, Schoepfer R, et al.: Heteromeric NMDA receptors: molecular and functional distinction of subtypes. Science. 1992; 256(5060): 1217-21.

PubMed Abstract | Publisher Full Text

Nowak L, Bregestovski $\mathrm{P}$, Ascher $\mathrm{P}$, et al:: Magnesium gates glutamate-activated channels in mouse central neurones. Nature. 1984; 307(5950): 462-465. PubMed Abstract | Publisher Full Text

Paoletti $\mathrm{P}$, Bellone $\mathrm{C}$, Zhou Q: NMDA receptor subunit diversity: impact on receptor properties, synaptic plasticity and disease. Nat Rev Neurosci. 2013. 14(6): 383-400.

PubMed Abstract | Publisher Full Text

Watanabe M, Inoue $\mathrm{Y}$, Sakimura $\mathrm{K}$, et al.: Developmental changes in distribution of NMDA receptor channel subunit mRNAs. Neuroreport. 1992; 3(12): 1138-1140. PubMed Abstract

Williams K: Ifenprodil discriminates subtypes of the $\mathrm{N}$-methyl-D-aspartate receptor: selectivity and mechanisms at recombinant heteromeric receptors. Mol Pharmacol. 1993; 44(4): 851-9.

PubMed Abstract

Wyllie DJ, Livesey MR, Hardingham GE: Influence of GluN2 subunit identity on NMDA receptor function. Neuropharmacology. 2013; 74: 4-17. PubMed Abstract | Publisher Full Text | Free Full Text 


\section{Open Peer Review}

\section{Current Peer Review Status: $\checkmark$ ?}

Version 1

Reviewer Report 19 April 2017

https://doi.org/10.21956/wellcomeopenres.11843.r21703

(C) 2017 Mony L. This is an open access peer review report distributed under the terms of the Creative Commons Attribution License, which permits unrestricted use, distribution, and reproduction in any medium, provided the original work is properly cited.

\section{Laetitia Mony \\ INSERM (French National Institute of Health and Medical Research), Paris, France}

The current manuscript describes the in vitro functional characterization of a GluN2A mutation, GluN2A ${ }^{\text {R586K }}$, found in a patient with intellectual disability and either epilepsy or abnormal EEG ${ }^{1}$. A subsequent number of mutations within the GRIN1, GRIN2A and GRIN2B genes were found in patients with neurological disorders ${ }^{1-3}$. In vitro functional characterization revealed that some of these mutations had major impacts on NMDA receptor expression, biophysical and pharmacological properties (see, for example, Swanger et al. and Serraz et al. ${ }^{4,5}$ ). However, although predicted to be "possibly damaging" by Endele et al. ${ }^{1}$, the functional effect of the GluN2A R586K mutation had never been investigated. Since R586 is located in the M1-M2 loop, close to the pore, they logically investigated the permeation and block properties of the GluN1/ GluN2AR586K mutant and found that magnesium block, conductance and mean open times were unaffected in Xenopus oocytes and cultured neurons. They thus concluded that this mutation is probably benign.

The manuscript is written well and the experiments are clearly described in the experimental section. I have however several reservations concerning the experimental work and some suggestions for the discussion, which I hope might improve the quality of the manuscript.

1. Magnesium block: The authors only test the effect of one concentration (1 $\mathrm{mM}$ ), at one holding potential. Although $1 \mathrm{mM}$ magnesium is close to the physiological concentration, it seems that this concentration is saturating for GluN1/GluN2A receptors at $-60 \mathrm{mV}$, which may hide differences in magnesium sensitivities between wt and R586K receptors. The authors should test different concentrations and different holding potentials to be able to conclude that magnesium block is unaffected by the mutation. Ideally, full current-voltage relationships should be measured at different magnesium concentrations.

2. Pore opening properties: In their single channel experiments, the authors measure the single channel conductance and the mean open time. What about the open probability? Is it also unaffected by the mutation?

3. Limiting the functional studies to the sole permeation and block properties of NMDARs is very restrictive. Although the mutation is located far from the extracellular domains, where 
most pharmacological agents act, it could very well affect the pharmacological properties of the receptor. For example, it has been shown that phosphorylation of residues located in the intracellular C-terminal tail could influence affinity for zinc, which binds in the extracellular $\mathrm{N}$-terminal domain ${ }^{6}$. Therefore, to conclude that the mutation has no clear functional effect, the authors should have measured the mutant sensitivity for the agonists glutamate (or NMDA) and glycine, its kinetics of activation and deactivation, as well as its sensitivity for the endogenous allosteric modulators zinc and protons.

4. Relative to point \#3, in the discussion section, where the authors state "The lack of functional consequences of the GluN2A ${ }^{\text {R586K }}$ variant", they should say "The lack of consequences on the permeation and block properties of the GluN2A ${ }^{\text {R586K }}$ variant". Indeed, the variant could have functional consequences that were not investigated in the study.

5. In the discussion, the authors mention that "It is also possible that the variant affects other properties that have not been investigated in this study". The authors should discuss in more details what properties could be affected by the variant (as previously mentioned, pharmacological properties, but also trafficking, downstream signaling...).

6. Relative to points \#3-5, the authors can certainly conclude that the mutation does not induce any dramatic effect on NMDAR function, which would show even at saturating agonist and magnesium concentrations. However, to conclude that it is "probably benign" would require further characterization of this variant.

\section{References}

1. Endele S, Rosenberger G, Geider K, Popp B, et al.: Mutations in GRIN2A and GRIN2B encoding regulatory subunits of NMDA receptors cause variable neurodevelopmental phenotypes. Nat Genet . 2010; 42 (11): 1021-6 PubMed Abstract | Publisher Full Text

2. Burnashev N, Szepetowski P: NMDA receptor subunit mutations in neurodevelopmental disorders.Curr Opin Pharmacol. 2015; 20: 73-82 PubMed Abstract | Publisher Full Text

3. Takasaki Y, Koide T, Wang C, Kimura H, et al.: Mutation screening of GRIN2B in schizophrenia and autism spectrum disorder in a Japanese population.Sci Rep. 2016; 6: 33311 PubMed Abstract | Publisher Full Text

4. Swanger SA, Chen W, Wells G, Burger PB, et al.: Mechanistic Insight into NMDA Receptor Dysregulation by Rare Variants in the GluN2A and GluN2B Agonist Binding Domains.Am J Hum Genet. 2016; 99 (6): 1261-1280 PubMed Abstract | Publisher Full Text

5. Serraz B, Grand T, Paoletti P: Altered zinc sensitivity of NMDA receptors harboring clinicallyrelevant mutations.Neuropharmacology. 2016; 109: 196-204 PubMed Abstract | Publisher Full Text 6. Zheng F, Gingrich MB, Traynelis SF, Conn PJ: Tyrosine kinase potentiates NMDA receptor currents by reducing tonic zinc inhibition. Nat Neurosci. 1998; 1 (3): 185-91 PubMed Abstract | Publisher Full Text

\section{Is the work clearly and accurately presented and does it cite the current literature? Yes}

Is the study design appropriate and is the work technically sound?

Partly 
Are sufficient details of methods and analysis provided to allow replication by others? Yes

If applicable, is the statistical analysis and its interpretation appropriate?

I cannot comment. A qualified statistician is required.

Are all the source data underlying the results available to ensure full reproducibility?

Yes

Are the conclusions drawn adequately supported by the results?

Partly

Competing Interests: No competing interests were disclosed.

Reviewer Expertise: Structure-function, pharmacology, neuroscience

I confirm that I have read this submission and believe that I have an appropriate level of expertise to confirm that it is of an acceptable scientific standard, however I have significant reservations, as outlined above.

Reviewer Report 06 April 2017

https://doi.org/10.21956/wellcomeopenres.11843.r21096

(c) 2017 Mellor I et al. This is an open access peer review report distributed under the terms of the Creative Commons Attribution License, which permits unrestricted use, distribution, and reproduction in any medium, provided the original work is properly cited.

Ian R. Mellor

School of Life Sciences, University of Nottingham, Nottingham, UK Helen Knight

University of Nottingham, Nottingham, UK

Recent large scale exome sequencing studies of disease and biomedically relevant quantitative traits have revealed a high frequency of rare coding loss of function mutations and amino acid changing missense variants across the genome ${ }^{1,2}$. It is now also recognised that such rare coding variants may not necessarily have a functional impact. One such category of coding variant commonly known as Variants of Unknown Significance (VUS), are typically composed of missense mutations (amino acid substitutions) and are often carried in a heterozygous state. Whether such variants have a functional effect, and potentially could be pathogenic, depend on a number of factors including the mutated gene and gene product, genetic sequence context of the variant, and, where in the encoded protein the amino acid substitution occurs. However, certain families of genes have consistently been indicated to contain genetic variation associated with specific diseases. One such family of genes encode for glutamate neurotransmitter receptor subunits and have been associated with risk for developing a variety of brain diseases. 
The manuscript describes an in vitro functional study of a missense variant within the NMDA type glutamate receptor subunit, GluN2A (gene GRIN2A), which had originally been identified in the heterozygous state in an individual with epilepsy and/or abnormal EEG and reported by Endele et al., 2010. The variant was reported to be inherited and not arising de novo, which is often considered to have a higher probability of being a pathogenic mutation. Mutations within GRIN2A have previously been reported to cause a range of epilepsy syndromes consistent with an inherited autosomal dominant Mendelian manner ${ }^{3,4}$ and also to contribute to risk for common complex neurodevelopmental diseases such as severe intellectual disability ${ }^{5}$. The question of whether this VUS has a functional effect is indeed very pertinent.

We find that the manuscript is written well with the aims and methods appropriately detailed. We have some comments regarding the experimental work and some suggestions for inclusion in the introduction and discussion sections, which we hope will contribute to the quality of the manuscript.

\section{Abstract}

The abstract needs to include the human gene name (GRIN2A) and that rare variants have been identified within NMDA subunit genes in individuals with neurodevelopmental disorders as well as in unaffected individuals.

\section{Introduction}

It would be useful to have more of an overview of how genetic variation within GRIN2A is thought to contribute to brain disease, i.e. genotype-phenotype relationships (e.g. type of mutations, mode of inheritance, 'causative' for disease or associated with increased risk of disease).

It should be stated in the introduction that in silico tools had been used to predict the function consequence of this variant (as presented by Endele et al., 2010, supplementary Table 2) and that such prediction tools including others not used by Endele et al., indicate that this variant is predicted to be consistently 'possibly damaging' as opposed to benign. This provides good justification to study the variant. It is also probably worth pointing out the severity of the amino acid substitution in the studied variant, i.e. it is a conservative change.

Where discussing NMDARs as a "molecular coincidence detector", it might be worth mentioning the requirement for glycine as co-agonist to glutamate too.

\section{Methods}

The methods were very well explained and are entirely repeatable.

\section{Results}

The first part of the results section shows the sensitivity of the NMDARs containing WT or mutated GluN2A to $\mathrm{Mg}^{2+}$. The chosen concentration of $\mathrm{Mg}^{2+}$ is indeed around the expected physiological concentration, but because it is more-or-less a saturating inhibitory concentration it would be harder to pick up any changes in sensitivity. Repeating the experiment with a lower concentration of $\mathrm{Mg}^{2+}$ or better still obtaining an $\mathrm{IC}_{50}$ would give more substance to the claim that this property is unchanged. The same is true for the experiments with transfected neurons where inhibition is very close to $100 \%$.

The methods section states that oocytes were clamped at several holding potentials but data is 
only shown for $-60 \mathrm{mV}$. It would strengthen the claim that $\mathrm{Mg}^{2+}$ sensitivity is unchanged if data for other holding potential is shown and/or discussed. Small changes to the voltage-dependence of inhibition could be responsible for defective physiological function of NMDARs.

The responses of transfected neurons to NMDA in Fig. 2A-B may imply small alterations to desensitisation properties. Was there any measurable difference?

In the single channel study, was there any difference in the mean closed time, and what was the outcome of the dwell time (open and closed) analysis mentioned in the methods?

\section{Discussion}

In paragraph 2, more details are needed to explain why there may have been differences between the present findings and those previously reported for mutations found to have an impact on NMDA subunit properties. Indeed, with the breadth of type of mutations identified for different brain diseases and their mode of inheritance (loss of function, gain of function, het state) would you expect the same in terms of observable change of function?

The authors state that this variant has been identified in two individuals out of 60,706 in the ExAC database and hence the authors suggest this provides additional evidence that this variant is not pathogenic and the occurrence in an individual with epilepsy was coincidental. However, the ExAC consortium includes genome data from individuals belonging to disease cohort studies as well as healthy 'control' individuals. All that is currently published about these two individuals who have this variant is that they do not have severe paediatric disease. It may be that these individuals belong to disease cohorts and have a diagnosis of a brain disease including neurodevelopmental disorders.

It is quite possible that the genotype-phenotype relationship is not as straight forward as the original hypothesis, i.e. that this variant in isolation has a functional effect and that the effect on subunit properties is directly through an amino acid change. For example, several coding variants are thought to have an effect in tandem with other coding mutations (compound heterozygous mutations). Alternatively, other genomic/epigenetic mechanisms may be disrupted by this variant and underlie transcription and translation processes which affect subunit abundance.

\section{References}

1. UK10K Consortium, Walter K, Min JL, Huang J, et al.: The UK10K project identifies rare variants in health and disease.Nature. 2015; 526 (7571): 82-90 PubMed Abstract | Publisher Full Text

2. Lek M, Karczewski K, Minikel E, Samocha K, et al.: Analysis of protein-coding genetic variation in 60,706 humans. Nature. 2016; 536 (7616): 285-291 Publisher Full Text

3. Carvill GL, Regan BM, Yendle SC, O'Roak BJ, et al.: GRIN2A mutations cause epilepsy-aphasia spectrum disorders.Nat Genet. 2013; 45 (9): 1073-6 PubMed Abstract | Publisher Full Text 4. Lemke JR, Lal D, Reinthaler EM, Steiner I, et al.: Mutations in GRIN2A cause idiopathic focal epilepsy with rolandic spikes.Nat Genet. 2013; 45 (9): 1067-72 PubMed Abstract | Publisher Full Text

5. de Ligt J, Willemsen MH, van Bon BW, Kleefstra T, et al.: Diagnostic exome sequencing in persons with severe intellectual disability.N Engl J Med. 2012; 367 (20): 1921-9 PubMed Abstract | Publisher Full Text

\section{Is the work clearly and accurately presented and does it cite the current literature?}


Partly

Is the study design appropriate and is the work technically sound?

Partly

Are sufficient details of methods and analysis provided to allow replication by others? Partly

If applicable, is the statistical analysis and its interpretation appropriate? Partly

Are all the source data underlying the results available to ensure full reproducibility? Partly

Are the conclusions drawn adequately supported by the results? Partly

Competing Interests: No competing interests were disclosed.

We confirm that we have read this submission and believe that we have an appropriate level of expertise to confirm that it is of an acceptable scientific standard, however we have significant reservations, as outlined above.

Reviewer Report 05 April 2017

https://doi.org/10.21956/wellcomeopenres.11843.r21350

(c) 2017 Chazot P. This is an open access peer review report distributed under the terms of the Creative Commons Attribution License, which permits unrestricted use, distribution, and reproduction in any medium, provided the original work is properly cited.

\section{Paul L. Chazot}

School of Biological and Biomedical Science, Durham University, Durham, UK

This is a well written, straight-forward study which has been performed well.

Explanation of why this particular mutation was selected over the many choices in key regions of the GluN2A subunit would be useful.

As the authors allude to, this not a comprehensive study of the short and long term functional property changes which may be linked to the mutation.

Is the work clearly and accurately presented and does it cite the current literature? Partly

Is the study design appropriate and is the work technically sound? 


\section{Partly}

Are sufficient details of methods and analysis provided to allow replication by others? Partly

If applicable, is the statistical analysis and its interpretation appropriate?

Partly

Are all the source data underlying the results available to ensure full reproducibility? Partly

Are the conclusions drawn adequately supported by the results?

Partly

Competing Interests: No competing interests were disclosed.

I confirm that I have read this submission and believe that I have an appropriate level of expertise to confirm that it is of an acceptable scientific standard. 